\title{
Arctiini Leach, [1815] (Lepidoptera, Erebidae, Arctiinae) of the Brazilian Amazon. V - Subtribes Arctiina Leach, [1815], Callimorphina Walker, [1865] and Spilosomina Seitz, 1910
}

\author{
José A. Teston $^{1 * \mathbb{B} \text { \& Viviane G. Ferro }}{ }^{2}$ [D \\ ${ }^{1}$ Universidade Federal do Oeste do Pará, Instituto de Ciências da Educação, Laboratório de Estudos de Lepidópteros \\ Neotropicais, Rua Vera Paz s/n, CEP 68040-255, Santarém, PA, Brasil. \\ ${ }^{2}$ Universidade Federal do Rio Grande do Sul, Instituto de Biociências, Departamento de Zoologia, Laboratório de Ecologia \\ de Insetos, Av. Bento Gonçalves 9500, Bloco IV, Prédio 43435, Sala 218, CEP 91501-970, Porto Alegre, RS, Brasil. \\ *Corresponding author: José A. Teston, e-mail: jateston@gmail.com
}

TESTON, J.A., FERRO, V.G. Arctiini Leach, [1815] (Lepidoptera, Erebidae, Arctiinae) of the Brazilian Amazon. V - Subtribes Arctiina Leach, [1815], Callimorphina Walker, [1865] and Spilosomina Seitz, 1910. Biota Neotropica 20(3): e20200989. https://doi.org/10.1590/1676-0611-BN-2020-0989

\begin{abstract}
The Arctiina, Callimorphina and Spilosomina moths comprise 340 species in the neotropics. Here we provide a list of Arctiina, Callimorphina and Spilosomina species from the Brazilian Amazon. The list was produced from specimens deposited in the most important Brazilian collections and from literature data. We registered 17 species of Arctiina, two of Callimorphina and 16 of Spilosomina. The proportion of Brazilian Amazon Callimorphina (28.6\%) and Arctiina (19.1\%) in relation to Neotropical fauna were nearly to those found for other Arctiini subtribes in the Brazilian Amazon. However, the Spilosomina records were extremely low, corresponding to only $6.6 \%$ of the Neotropical species. Belém, Fonte Boa and Santarém were the municipalities with the highest number of registered species, with 14, 9 and 8, respectively. As this is the last article on the fauna of the Arctiini subtribes of the Brazilian Amazon, we summarize the main patterns observed for the tribe and identify the main knowledge gaps regarding this taxon.
\end{abstract}

Keywords: Amazon; Tiger moths; Inventory; Noctuoidea.

Arctiini Leach, [1815] (Lepidoptera, Erebidae, Arctiinae) da Amazônia Brasileira. V - Subtribos Arctiina Leach, [1815], Callimorphina Walker, [1865] e Spilosomina Seitz, 1910

Resumo: As mariposas Arctiina, Callimorphina e Spilosomina totalizam 340 espécies na região Neotropical. Neste trabalho, nós apresentamos uma lista das espécies de Arctiina, Callimorphina e Spilosomina que ocorrem na Amazônia brasileira. A lista foi produzida através de observação de espécimes depositados nas mais importantes coleções brasileiras e também através de dados da literatura. Foram registradas 17 espécies de Arctiina, duas de Callimorphina e 16 de Spilosomina. A proporção de Callimorphina (28,6\%) e Arctiina $(19,1 \%)$ em relação à fauna neotropical foi semelhante à encontrada para as outras subtribos de Arctiini da Amazônia brasileira. No entanto, os registros de Spilosomina foram extremamente baixos, correspondendo a apenas 6,6\% das espécies neotropicais. Belém, Fonte Boa e Santarém foram os municípios com maior número de espécies registradas, com 14, 9 e 8, respectivamente. Como este é o último artigo sobre a fauna das subtribos de Arctiini da Amazônia brasileira, nós resumimos os principais padrões observados para a tribo e identificamos as principais lacunas de conhecimento sobre esse táxon.

Palavras-chave: Amazônia; Mariposas-tigre; Inventário; Noctuoidea. 


\section{Introduction}

There are currently 1,023 Arctiini moths referred to the Brazilian Amazon, including 273 species of Ctenuchina (Teston et al. 2019a), 219 species of Euchromiina (Teston \& Ferro 2019), 62 species of Pericopina (Teston \& Ferro 2016a) and 469 species of Phaegopterina (Teston \& Ferro 2016b). However, it is still not certain how many species of the Arctiina, Calimorphina and Spilosomina subtribes exist in the Brazilian Amazon region.

The Arctiina and Callimorphina moths have a worldwide distribution (Weller et al. 2009). In the neotropic there are seven genera and 89 species of Arctiina and there is one genus and seven species of Callimorphina (Vincent \& Laguerre 2014). In adults of Arctiina the size varies from medium to large and the coloring is also varied, with spots and stripes. Male genitalia are simple or reduced. Female pheromone glands can be swollen, divided, and digitated. Larvae have short hair and several species are polyphagous, feeding on plants with pyrrolizidine alkaloids (Weller et al. 2009).

Several Callimorphina species tend to be large and brightly colored, and some are diurnal. The morphology of adults, especially in the male genitalia, varies, and in most of them there is a reduced counter-tympanal hood. Larvae feeding on various herbaceous plants, including plants with pyrrolizidine alkaloids (Weller et al. 2009).

The Spilosomina moths are also cosmopolitan (Schmidt 2009). In the Neotropics there are 23 genera and 244 species (Vincent \& Laguerre 2014). Adults are medium to large in size and vary in color. Larvae feed on low-growth herbaceous plants, and are more common in non-forest habitats, typically xeric forests, savannas, prairies, and wetlands (Schmidt 2009).

The caterpillars of some species present in these three sub-tribes are polyphagic and feed on plants of economic importance, but they are not pests of any importance (Schmidt 2009; Weller et al. 2009 and Teston et al. 2019b).

Here, we present a list of Arctiina, Callimorphina and Spilosomina moths occurring in the Brazilian Amazon. In this article we conclude the series of inventories of Arctiini for the Brazilian Amazon (Teston \& Ferro 2016ab, Teston \& Ferro 2019 and Teston et al. 2019a).

\section{Materials and Methods}

We intensively searched the literature and examined specimens from entomological collections of the Instituto Nacional de Pesquisas na Amazônia (INPA; Manaus), Museu Paraense Emilio Goeldi (MPEG; Belém), Coleção Becker (VOB; Camacan), Coleção Entomológica Padre Jesus Santiago Moure of the Universidade Federal do Paraná (DZUP; Curitiba), Fundação Instituto Oswaldo Cruz (FIOC; Rio de Janeiro), Museu de Zoologia of the Universidade de São Paulo (MZUSP; São Paulo), Museu Nacional of the Universidade Federal do Rio de Janeiro (MNRJ; Rio de Janeiro), and Laboratório de Estudos de Lepidópteros Neotropicais (LELN) of the Universidade Federal do Oeste do Pará (UFOPA; Santarém). To identify the species, we used literature (Hampson 1901, 1920, Seitz 1919-1925, Vincent \& Laguerre 2014,
Watson 1971, 1973) and specimens deposited in the visited collections. The systematic organization to generic level follows Vincent \& Laguerre (2014).

The geographical coordinates of the localities in the Brazilian Amazon with Arctiinae records were obtained from the Geo Loc tool of "Species Link date \& tools" (http://splink.cria.org.br/geoloc) and Google Earth (https://earth.google.com/web/). The list is organized alphabetically. Species and records without precise location data, and those from locations that belong to more than one biome (e.g., Cerrado and Amazon) were not included in the list.

\section{Results}

We registered 17 species of Arctiina, 2 of Callimorphina and 16 of Spilosomina (Table 1). Of the total of 35 species, five were new occurrences for the Brazilian Amazon (three Arctiina and two Spilosomina) (indicated by "NEW" in the Table 1). One Spilosomina species appear as new records for the municipalities and their respective States (indicated by "AMZ"). In total, 41 (5.2\%) Amazonian municipalities had moths species records of three Subtribes (Table 2 and Figure 1). Belém (PA), Fonte Boa (AM), and Santarém (PA) were the municipalities with the highest number of species, with 14,9 , and 8 , respectively.

We recorded six genera, of which one were monospecific. The genera Virbia Walker, 1854 presented the highest number of species (13), followed by Hypercompe Hübner, [1819] (8) and Paracles Walker, 1855 (7). The species with the highest number of locality records was Utetheisa ornatrix (Linnaeus, 1758) (with 14), followed by Virbia subapicalis (Walker, 1854) (11), and Paracles laboulbeni (Bar, 1873) (10). Eigtheen species (51.4\%) occurred in only one locality (Table 1).

\section{Discussion}

We consider low the total number of records for these three subtribes for the Brazilian Amazon (35). This value corresponds to only $10.3 \%$ of the Neotropical fauna (340, Vincent \& Laguerre 2014, Teston et al. 2019b) and are slightly larger than the southest Brazilian State (Rio Grande do Sul, 29, Ferro \& Teston 2009), which has an area approximately 18 times smaller and a latitude about 6 times larger than the Brazilian Amazon. Considering the subtribes separately, the proportion of Brazilian Amazon Callimorphina (28.6\%) and Arctiina (19.1\%) in relation to Neotropical fauna were nearly to those found for other subtribes in the Brazilian Amazon (between 17 and 31\%, Teston \& Ferro 2016ab, Teston \& Ferro 2019, Teston et al. 2019a, Vincent \& Laguerre 2014). However, the Spilosomina records were extremely low, corresponding to only $6.6 \%$ of the 244 Neotropical species (Vincent \& Laguerre 2014). A possible explanation for this low richness would be the difficulty in identifying the Spilosomina species. Paracles and Hypercompe, for example, are genera with a large number of species with similar color and size patterns. As we considered in our study only the species with no doubtful identification, many species (including Paracles and Hypercompe) were not included in our list. However, the low number of species in this subtribe in the Amazon may indicate that this taxon is less diverse at low latitudes. 
Table 1. Arctiina, Callimorphina and Spilosomina (Erebidae, Arctiinae, Arctiini) species of the Brazilian Amazon. The record column shows the Brazilian state in abbreviated form followed by municipality. The name of the locality is enclosed in braces and the author of the first record is in parentheses. * New record. States abbreviations: $\mathrm{AM}=$ Amazonas, $\mathrm{AP}=$ Amapá, $\mathrm{MA}=$ Maranhão, $\mathrm{MT}=$ Mato Grosso, $\mathrm{PA}=$ Pará, $\mathrm{RO}=$ Rondônia and $\mathrm{RR}=\mathrm{Roraima}$.

\begin{tabular}{|c|}
\hline Subtribe / Species \\
\hline Arctiina Leach, [1815] \\
\hline 1. Pseudalus affinis Rothschild, 1933 \\
\hline 2. Pseudalus aurantiacus Rothschild, 1909 \\
\hline 3. Pseudalus leos (Druce, 1898) \\
\hline 4. Pseudalus limona Schaus, 1896 \\
\hline 5. Virbia divisa (Walker, 1854) ${ }^{\mathrm{NEW}}$ \\
\hline 6. Virbia dotata (Walker, [1865]) \\
\hline 7. Virbia egaca (Walker, [1865]) \\
\hline 8. Virbia epione Druce, 1911 \\
\hline 9. Virbia hypophaea Hampson, 1901 \\
\hline 10. Virbia medarda (Stoll, [1781]) \\
\hline
\end{tabular}

11. Virbia minuta (R. Felder, 1874)

12. Virbia ovata Rothschild, $1910^{\mathrm{NEW}}$ Record

13. Virbia palmeri (Druce, 1911)

14. Virbia parva Schaus, 1892

15. Virbia satara Seitz, 1919

AM, Fonte Boa (Rothschild 1933)

PA, [Belém] (Rothschild 1922)

AM, Fonte Boa (Rothschild 1910b); PA, Belém*

PA, Benevides*, Santarém (Valente et al. 2018)

AM, Fonte Boa*

AM, Manaus (Hampson 1901), Tefé \{Ega\} (Walker [1865])

AM, Tefé $\{\mathrm{Ega}\}$ (Walker [1865])

PA, Belterra \{National Forest of Tapajós\} (Freitas 2014)

PA, [Belém] (Rothschild 1922)

[AM], Amazonas [river] (Hampson 1901); MA, Açailândia*; PA, Belém*, Belterra

\{National Forest of Tapajós\} (Freitas 2014)

[AM], Amazonas river (R. Felder 1874)

AM, Manaus*; PA, Santarém*

PA, [Belém] (Rothschild 1922)

16. Virbia subapicalis (Walker, 1854)

PA, [Belém] (Rothschild 1922)

AM, Fonte Boa*; RO, Jarú*; PA, Almeirim (Hawes et al. 2009)

AM, Fonte Boa (Rothschild 1910a), Tefé \{Ega\} (Walker 1854); PA, Altamira (Teston and Delfina 2010), Belterra \{National Forest of Tapajós\} (Freitas 2014), Itaituba (Rothschild 1910a), Marabá*, Santarém (Valente et al. 2018), São Félix do Xingu \{Serra do Pardo National Park\} (Teston \& Correa 2015); RO, Cacaulândia*, Candeias do Jamari*, Porto Velho*

17. Virbia underwoodi Druce, $1911^{\text {NEW }}$ Callimorphina Walker, [1865]

18. Utetheisa ornatrix (Linnaeus, 1758) AM, Alto Solimões (Travassos 1946), Benjamin Constant (Travassos 1946), São Paulo de Olivença (Travassos 1946), Manaus (Bryk 1953); AP, Santana*; MA, Açailândia*; PA, (Travassos 1946), Altamira (Teston and Delfina 2010), [Belém] (Rothschild 1922), Belterra \{National Forest of Tapajós $\}$ (Freitas 2014), Chaves (Hampson 1901), Mojuí dos Campos*, Santarém*, São Félix do Xingu \{Serra do Pardo National Park\} (Teston \& Correa 2015), Soure*; RO, Cacaulândia*

19. Utetheisa pulchella (Linnaeus, 1758) PA, Mojuí dos Campos (Teston et al. 2019b) Spilosomina Seitz, 1910

20. Hypercompe abdominalis (Walker, [1865])

AM, Rio Purus (Bryk 1953), São Paulo de Olivença*; PA, [Belém] (Hampson 1901), Ourém*, Santarém*, Tucuruí*

21. Hypercompe alpha (Oberthur, 1881)

22. Hypercompe brasiliensis (Oberthür, 1881) ${ }^{\mathrm{AMZ}}$ PA, Almeirim (Hawes et al. 2009)

23. Hypercompe cunigunda (Stoll, [1781]) AM, [Santa Isabel do Rio Negro] \{Rio Preto $\}^{*}$

AM, São Gabriel da Cachoeira \{Querari\}*, São Paulo de Olivença*; MA, Açailândia*; PA, [Belém] (Rothschild 1922), Marabá*, São Félix do Xingu \{Serra do Pardo National Park (Teston \& Correa 2015); RO, Cacaulândia*; RR, Alto Alegre*

24. Hypercompe detecta (Oberthür, 1881)

25. Hypercompe laeta (Walker, 1855) NEW PA, [Belém] (Oberthür 1881)

26. Hypercompe marcescens (R. Felder, 1874)

MT, Sinop*

27. Hypercompe turruptianoides (Rothschild, 1910)

28. Isia alcumena (Berg, 1882)

29. Paracles brunnea (Hübner, [1831]) NEW

[AM], Amazonas river (R. Felder 1874)

30. Paracles contraria Walker, 1855

31. Paracles juruana (Butler, 1878)

AM, [Atalaia do Norte] \{Santo Antônio do Javari\} (Rothschild 1910a)

PA, Altamira (Delfina and Teston 2013); RO, Cacaulândia*

PA, Santarém*

AP, Serra do Navio*; PA, [Belém] (Walker 1855), Capitão Poço*, Santarém (Hampson 1901), Viseu*

AM, [Atalaia do Norte] \{Santo Antônio do Javari\} (Rothschild 1910b), [Carauari]

Rio Juruá (Butler 1878), Codajás (Rothschild 1910b), Fonte Boa (Rothschild 1910b),

Manacapuru to Tefé (Rothschild 1910b); RO, Porto Velho \{Calama\} (Rothschild 1910b)

32. Paracles klagesi (Rothschild, 1910)

AM, Fonte Boa (Rothschild 1910b)

33. Paracles laboulbeni (Bar, 1873)

AM, [Iranduba] \{Lago Janauarí, Rio Negro\}(Adis 1983), [Manaquiri] \{Lago Janauacá, Rio Solimões\} (Adis 1983), [Manaus] \{Manaus-Itacoatiara highway AM-010, Km 21 and Km 45\}(Adis 1983); PA, Altamira (Teston and Delfina 2010), [Belém] (Rothschild 1922), Gur[u]pá (Hampson 1901), [Prainha] (Butler 1878), Santarém*, São Félix do Xingu \{Serra do Pardo National Park\} (Teston \& Correa 2015)

34. Paracles sericea (Schaus, 1896)

AM, Itacoatiara (Bryk 1953), Parintins (Bryk 1953)

35. Paracles tenuis (Berg, 1877)

AM, [Atalaia do Norte] \{Santo Antônio do Javari\} (Rothschild 1910b), Codajás (Rothschild 1910b), Fonte Boa (Rothschild 1910b), Tefé to Fonte Boa (Rothschild 1910b); PA, [Belém] (Rothschild 1922); RO, Porto Velho \{Calama\} (Rothschild 1910b)

AMz Species recorded for states within the Amazon biome by Ferro and Diniz (2010), but without precise location and biome information, and Amazon biome by Ferro and Diniz (2007). So these species are new records for the municipalities. ${ }^{\mathrm{NEW}}$ New record for the Brazilian Amazon. 
Table 2. Geographic coordinates of municipalities and richness of the Arctiina, Callimorphina and Spilosomina species (Erebidae, Arctiinae, Arctini) in the Brazillian Amazon Biome.

\begin{tabular}{|c|c|c|c|c|c|}
\hline $\mathbf{N}^{\circ}$ & State & Municipality & Richness & Latitude & Longitude \\
\hline 1 & AP & Santana & 1 & $00^{\circ} 03^{\prime} 30^{\prime \prime S}$ & $51^{\circ} 10^{\prime} 54^{\prime \prime} \mathrm{W}$ \\
\hline 2 & AP & Serra do Navio & 1 & $00^{\circ} 53^{\prime} 45^{\prime \prime} \mathrm{N}$ & $52^{\circ} 00^{\prime} 07^{\prime \prime} \mathrm{W}$ \\
\hline 4 & $\mathrm{AM}$ & Benjamin Constant & 1 & $04^{\circ} 22^{\prime} 60^{\prime \prime} \mathrm{S}$ & $70^{\circ} 01^{\prime} 52^{\prime \prime} \mathrm{W}$ \\
\hline 5 & $\mathrm{AM}$ & Carauari & 1 & $05^{\circ} 03^{\prime} 01^{\prime \prime S}$ & $66^{\circ} 56^{\prime} 59^{\prime \prime} \mathrm{W}$ \\
\hline 8 & $\mathrm{AM}$ & Iranduba $\{$ Lago Janauarí\} & 1 & $03^{\circ} 12^{\prime} 45^{\prime \prime S}$ & $60^{\circ} 01^{\prime} 52^{\prime \prime} \mathrm{W}$ \\
\hline 9 & $\mathrm{AM}$ & Itacoatiara & 1 & $03^{\circ} 08^{\prime} 36^{\prime \prime S}$ & $58^{\circ} 26^{\prime} 39^{\prime \prime} \mathrm{W}$ \\
\hline 10 & $\mathrm{AM}$ & Manaquiri \{Lago Janauacá\} & 1 & $03^{\circ} 23^{\prime} 22^{\prime \prime} \mathrm{S}$ & $60^{\circ} 18^{\prime} 31^{\prime \prime} \mathrm{W}$ \\
\hline 11 & $\mathrm{AM}$ & Manaus & 5 & $03^{\circ} 06^{\prime} 07^{\prime \prime} \mathrm{S}$ & $60^{\circ} 01^{\prime} 30^{\prime \prime} \mathrm{W}$ \\
\hline 15 & $\mathrm{AM}$ & São Paulo de Olivença & 3 & $03^{\circ} 22^{\prime} 42^{\prime \prime S}$ & $68^{\circ} 52^{\prime} 20^{\prime \prime} \mathrm{W}$ \\
\hline 16 & $\mathrm{AM}$ & Tefé & 3 & $03^{\circ} 21^{\prime} 16^{\prime \prime} \mathrm{S}$ & $64^{\circ} 42^{\prime} 40^{\prime \prime} \mathrm{W}$ \\
\hline 17 & MA & Açailândia & 3 & $04^{\circ} 56^{\prime} 49^{\prime \prime S}$ & $47^{\circ} 30^{\prime} 17^{\prime \prime} \mathrm{W}$ \\
\hline 18 & MT & Sinop & 1 & $11^{\circ} 52 ' 51^{\prime \prime S}$ & $55^{\circ} 30^{\prime} 08^{\prime \prime} \mathrm{W}$ \\
\hline 19 & PA & Almeirim & 2 & $01^{\circ} 31^{\prime} 24^{\prime \prime S}$ & $52^{\circ} 34^{\prime} 54^{\prime \prime} \mathrm{W}$ \\
\hline 20 & $\mathrm{PA}$ & Altamira $^{\dagger}$ & 4 & $03^{\circ} 11^{\prime} 55^{\prime \prime S}$ & $52^{\circ} 10^{\prime} 15^{\prime \prime} \mathrm{W}$ \\
\hline 21 & $\mathrm{PA}$ & Belém & 14 & $01^{\circ} 27^{\prime} 21^{\prime \prime S}$ & $48^{\circ} 30^{\prime} 15^{\prime \prime} \mathrm{W}$ \\
\hline 22 & $\mathrm{PA}$ & Belterra $\{\text { National Forest of Tapajós }\}^{\dagger}$ & 4 & $03^{\circ} 01^{\prime} 05^{\prime \prime} \mathrm{S}$ & $54^{\circ} 58^{\prime} 10^{\prime \prime} \mathrm{W}$ \\
\hline 23 & PA & Benevides & 1 & $01^{\circ} 21^{\prime} 42^{\prime \prime S}$ & $48^{\circ} 14^{\prime} 40^{\prime \prime} \mathrm{W}$ \\
\hline 29 & PA & Mojuí dos Campos ${ }^{\dagger}$ & 2 & $02^{\circ} 41^{\prime} 44^{\prime \prime S}$ & $54^{\circ} 34^{\prime} 14^{\prime \prime} \mathrm{W}$ \\
\hline 30 & $\mathrm{PA}$ & Ourém & 1 & $01^{\circ} 33^{\prime} 07^{\prime \prime} \mathrm{S}$ & $47^{\circ} 06^{\prime} 52^{\prime \prime} \mathrm{W}$ \\
\hline 31 & PA & Prainha & 1 & $01^{\circ} 47^{\prime} 60^{\prime \prime S}$ & $53^{\circ} 28^{\prime} 47^{\prime \prime} \mathrm{W}$ \\
\hline 32 & $\mathrm{PA}$ & Santarém & 8 & $02^{\circ} 26^{\prime} 36^{\prime \prime} \mathrm{S}$ & $54^{\circ} 42^{\prime} 29^{\prime \prime} \mathrm{W}$ \\
\hline 33 & $\mathrm{PA}$ & São Félix do Xingu $\{\text { Serra do Pardo National Park }\}^{\dagger}$ & 4 & $05^{\circ} 46$ '26"S & $52^{\circ} 37^{\prime} 13^{\prime \prime} \mathrm{W}$ \\
\hline 34 & $\mathrm{PA}$ & Soure & 1 & $00^{\circ} 43^{\prime} 01 " \mathrm{~S}$ & $48^{\circ} 31^{\prime} 24^{\prime \prime} \mathrm{W}$ \\
\hline 35 & PA & Tucuruí & 1 & $03^{\circ} 42^{\prime} 01^{\prime \prime} \mathrm{S}$ & $49^{\circ} 42^{\prime} 00^{\prime \prime} \mathrm{W}$ \\
\hline 36 & PA & Viseu & 1 & $01^{\circ} 11^{\prime} 49 " \mathrm{~S}$ & $46^{\circ} 08^{\prime} 23^{\prime \prime} \mathrm{W}$ \\
\hline 37 & RO & Cacaulândia & 4 & $10^{\circ} 20^{\prime} 21^{\prime \prime S}$ & $62^{\circ} 53^{\prime} 43^{\prime \prime} \mathrm{W}$ \\
\hline 38 & RO & Candeias do Jamari & 1 & $08^{\circ} 48^{\prime} 35^{\prime \prime} \mathrm{S}$ & $63^{\circ} 41^{\prime} 44^{\prime \prime} \mathrm{W}$ \\
\hline 39 & RO & Jarú & 1 & $10^{\circ} 26^{\prime} 20^{\prime \prime} \mathrm{S}$ & $62^{\circ} 27^{\prime} 58^{\prime \prime} \mathrm{W}$ \\
\hline 40 & RO & Porto Velho & 3 & $08^{\circ} 45^{\prime} 43^{\prime \prime} \mathrm{S}$ & $63^{\circ} 54^{\prime} 13^{\prime \prime} \mathrm{W}$ \\
\hline 41 & RR & Alto Alegre & 1 & $02^{\circ} 53^{\prime} 45^{\prime \prime} \mathrm{N}$ & $61^{\circ} 29^{\prime} 51^{\prime \prime} \mathrm{W}$ \\
\hline
\end{tabular}

Geographic coordinates of municipality marked with $\dagger$ are the citations referred, other obtained by Google Earth or Geo Loc tool (see Materials and Methods). 


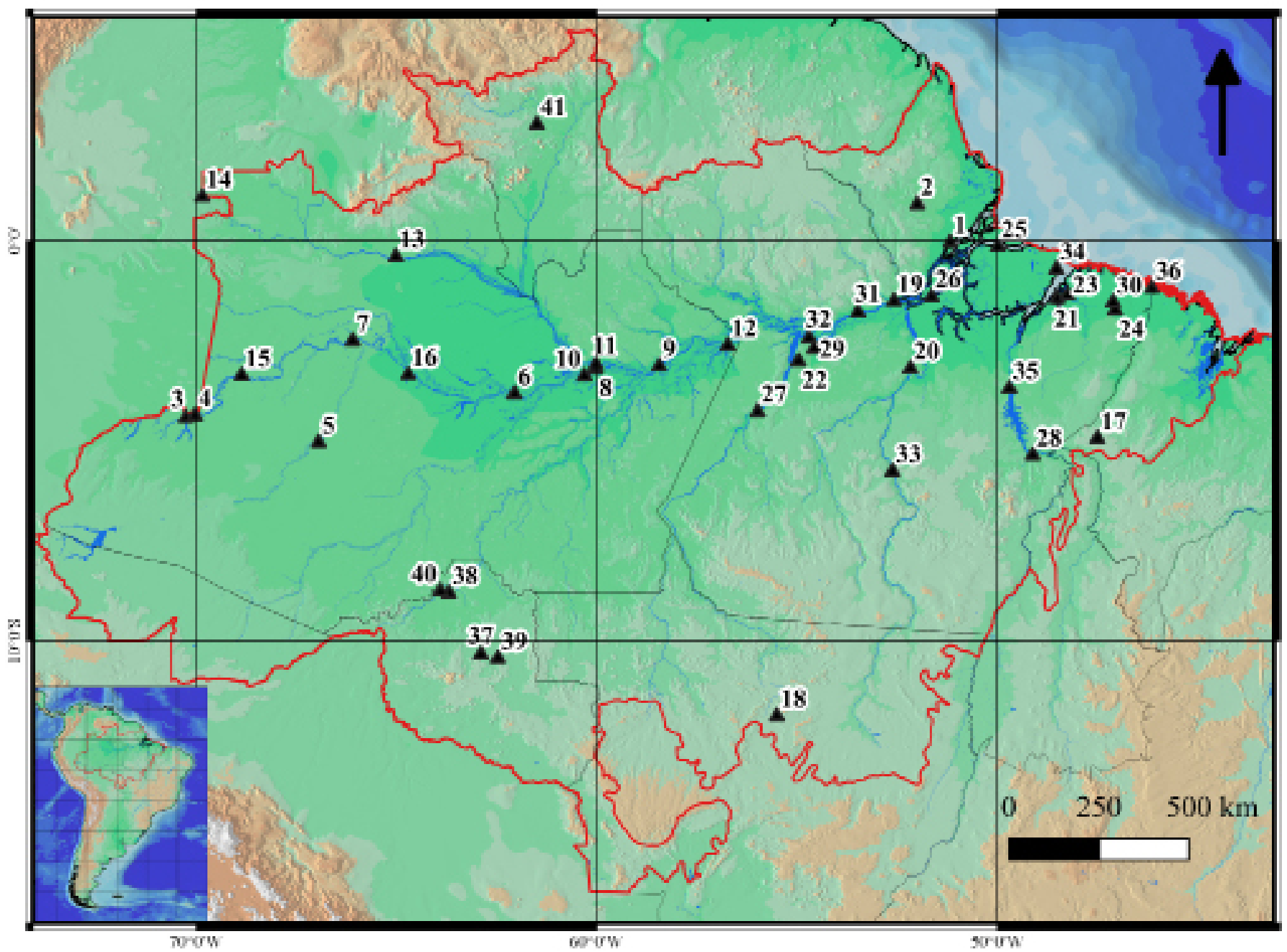

Figure 1. Geographic distribution of the Arctiina, Callimorphina and Spilosomina species records in the Brazillian Amazon. The numbers refer to the municipalities of Table 2.

In a Peruvian site (latitude 13S), for example, only 5 species of Spilosomina were sampled (Grados, 2002), but in the southernmost state of Brazil (Rio Grande do Sul, latitude about 30S) were recorded 26 species of Spilosomina (Ferro \& Teston 2009), 10 more species than the entire Amazon biome. Nevertheless, other samplings carried out at higher latitudes (between 22 and 32S) (but with a much smaller sample effort) found a low number of Spilosomina species: 7 in the Bosque Serrano de la provincia de Córdoba, Argentina (Beccacece et al. 2012), and 5 in the Chaco Serrano and Yungas Ecoregions, also in Argentina (Beccacece et al. 2016).

The highest richness for the three subtribes (Arctiina, Callimorphina and Spilosomina together) in an Amazonian site were 14, 9 and 8 species (Belém, Fonte Boa and Santarém, respectively). These values are similar to those found in well-sampled Atlantic Forest sites, as Boracéia, (10 species, Ferro \& Diniz 2007) and Joinville (11, Ferro et al. 2012). In the Cerrado well-sampled sites, however, were recorded only seven (Scherrer et al. 2013) and six (Moreno \& Ferro 2016) species of these three subribes.
With this paper we concluded the series of faunal inventories about Brazilian Amazon Arctiini (Teston \& Ferro 2016a, b, Teston \& Ferro 2019, Teston et al. 2019a). Some common patterns could be observed in these papers. First, there was a great overlap in relation to the locations with the highest number of Arctiini species records. Belém, the capital of the state of Pará, was among the three most diverse locations in all Arctiini inventory papers (Teston \& Ferro 2016a, b, Teston \& Ferro 2019, Teston et al. 2019a, this work), followed by Santarém (Teston \& Ferro 2019, Teston et al. 2019a, this work), Cacaulândia (Teston \& Ferro 2016a, Teston et al. 2019a) and Fonte Boa (Teston \& Ferro $2016 \mathrm{a}$, this work). This pattern was probably related to historical sampled effort (several naturalists sampled in the Amazon in the 19th and 20th centuries), and to the proximity/easer access to sampled sites and research institutions. Second, the number of Brazilian Amazon arctiid records was underestimaded for all subtribes. The tiger moth fauna was never sampled in the vast majority of the biome. 
The Legal Amazon comprises 775 muncipalities and there are sampled records in only 41 for Arctiina, Callimorphina and Spilosomina (this work), 48 for Pericopina (Teston \& Ferro 2016b), 69 for Phaegopterina (Teston \& Ferro 2016a), 71 for Euchromiina (Teston \& Ferro 2019), and 75 for Ctenuchina (Teston et al. 2019a). Besides, the sampling points are poorly distributed and usually restricted to more populated cities and along major rivers. In addition, the majority of the locations were insufficiently sampled, as observed by the large proportion of sites with only one species record (e.g. 58.5\% for Arctiina, Callimorphina and Spilosomina). Third, the Arctiini fauna was more diverse in humid than in xeric biomes. There are currently 1,058 Arctiini moths registred to the Brazilian Amazon, considering the subtribes Ctenuchina, Euchromiina, Pericopina and Phaegopterina (Teston \& Ferro 2016a, b, 2019, Teston et al. 2019a) and those listed in this study. The Arctiini richness of the the Brazilian Amazon is high but slightly lower than the Atlantic Forest (1,193 species, Ferro $\&$ Melo 2011). This suggest a pattern of higher diversity in humid forest environments since in the Cerrado biome there are only 595 Arctiini recorded species (Ferro \& Diniz 2010).

In order to suggest efficient conservation policies for the Amazon Arctiini fauna, it is urgent to intensify the sampling effort in this biome, both spatially (more locations, several strata and types of vegetation), and temporally (sampled also during the day, during several months/ years, throughout all nocturnal period). Besides, it is necessary a higher investment in taxonomy/systematic research on the Neotropical Arctiinae fauna to reduce the Linnean shortfalls. Finally, we think it is important to expand the studies for the Lithosiini tribe and to understand in more depth the issue of the low richness of Spilosomina in the Amazon.

\section{Acknowledgements}

We are indebted to the museum curators for allowing VGF's access to the collections under their care and for logistical support. This publication is part of the RedeLep "Rede Nacional de Pesquisa e Conservação de Lepidópteros", SISBIOTA-Brasil, CNPq (563332/2010-7).

\section{Author Contributions}

José A. Teston and Viviane G. Ferro: Substantial contribution in the concept and design of the study.

\section{Conflicts of Interest}

The authors declare that they have no conflict of interest related to the publication of this manuscript.

\section{Data availability}

The data are deposited in the respective collections mentioned in the Material and Methods.

\section{References}

ADIS, J. 1983. Eco-entomological observations from the Amazon. IV. Occurrence and feeding habits of the aquatic caterpillar Palustra laboulbeni Bar, 1873 (Arctiidae: Lepidoptera) in the vicinity of Manaus, Brazil. Acta Amaz. 13(1): 31-36.

BECCACECE, H.M., ZAPATA, A.I., VILLAFAÑE, N.A. \& DREWNIAK, M.E. 2012. Árctidos nocturnos (Lepidoptera: Erebidae: Arctiinae) del Bosque Serrano de Córdoba, Argentina. Rev. Soc. Entomol. Argent. 71(1-2): 99-103.

BECCACECE, H.M., ZEBALLOS, S.R. \& ZAPATA, A.I. 2016. Changes in Species Richness and Composition of Tiger Moths (Lepidoptera: Erebidae: Arctiinae) among Three Neotropical Ecoregions. PLoS ONE 11(9): e0162661.

BRYK, F. 1953. Lepidoptera aus dem amazonasgebiete und aus Peru gesammelt von Dr. Douglas Melin und Dr. Abraham Roman. Ark. zool. 5(1): 1-268.

BUTLER, A.G. 1878. On the Lepidoptera of the Amazons, collected by Dr James W. H. Trail during the years 1873 to 1875 . Trans. Entomol. Soc. Lond. 26(1): 39-84.

DELFINA, M.C. \& TESTON, J.A. 2013. Arctiinae (Lepidoptera, Arctiidae) ocorrentes em uma área de pastagem na Amazônia Oriental em Altamira, Pará, Brasil. Acta Amaz. 43(1): 81-90.

FELDER, C. \& FELDER, R. 1864-1875. Pl 75-120 (1874). In Reise der österreichischen fregatte novara um die Erde in den Jahren 1857, 1858, 1859 unter den Befehlen des Commodore B. Von Wüllestorf-Urbair. Zoologischer Theil, Zweiter Band, Zweite Abtheilung: Lepidoptera (C. Felder, R. Felder \& A.F. Rogenhofer, eds.). Staatsdruckerei, Vienna.

FERRO, V.G. \& DINIZ, I.R. 2007. Arctiidae (Insecta: Lepidoptera) da Estação Biológica de Boracéia (Salesópolis, São Paulo, Brasil). Biota Neotrop. 7(3): 331-338. http://dx.doi.org/10.1590/S1676-06032007000300033 (last access on $01 / 03 / 2020$ ).

FERRO, V.G. \& DINIZ, I.R. 2010. Riqueza e composição das mariposas Arctiidae (Lepidoptera) no Cerrado. In Cerrado: conhecimento quantitativo como subsídio para as ações de conservação (I.R. Diniz, J. Marinho-Filho, R.B. Machado \& R. Cavalcanti, eds.). Editora Thesaurus, Brasília, p.255-313.

FERRO, V.G. \& MELO, A.S. 2011. Diversity of tiger moths in a Neotropical hotspot: determinants of species composition and identification of biogeographic units. J. Insect Conserv. 15(5): 643-651.

FERRO, V.G., MELO, A.S. \& DINIZ, I.R. 2010. Richness of tiger moths (Lepidoptera: Arctiidae) in the Brazilian Cerrado: how much do we know? Zoologia 27(5): 725-731.

FERRO, V.G., RESENDE, I.M.H. \& DUARTE, M. 2012. Arctiinae (Lepidoptera: Erebidae) do estado de Santa Catarina, Brasil. Biota Neotrop. 12(4): 166-180. http://dx.doi.org/10.1590/S1676-06032012000400018 (last access on $29 / 02 / 2020$ ).

FERRO V.G. \& TESTON, J.A. 2009. Composição de espécies de Arctiidae (Lepidoptera) no sul do Brasil: relação entre tipos de vegetação e entre a configuração espacial do hábitat. Rev. Bras. Entomol. 53(2): 278-286.

FREITAS, M.P. de. 2014. Extratificação vertical de Arctiini (Lepidoptera, Erebidae, Arctiinae) na Floresta Nacional do Tapajós, Amazônia Oriental, Pará, Brasil. Dissertação de Mestrado, Universidade Federal do Oeste do Pará, Santarém.

GRADOS, J. 2002. Los Arctiidae y Sphingidae (Lepidoptera: Heterocera) del Santuario Histórico de Machu Picchu, Cuzco, Perú: estudio preliminar. Rev. Peru. Biol. 9(1): 16-22.

HAMPSON, G.F. 1901. Catalogue of the Lepidoptera Phalaenae in the British Museum. Catalogue of the Arctiadae (Arctianae) and Agaristidae in the collection of the British Museum. Taylor \& Francis, London.

HAMPSON, G.F. 1920. Catalogue of the Lepidoptera Phalaenae in the British Museum. Supplement. Volume II. Catalogue of the Lithosiadae (Arctianae) and Phalaenoididae in the collection of the British Museum. Taylor \& Francis, London.

HAWES, J., MOTTA, C. da S., OVERAL, W.L., BARLOW, J., GARDNER, T.A. \& PERES, C.A. 2009. Diversity and composition of Amazonian moths in primary, secondary and plantation forest. J. Trop. Ecol. 25(3): 281-300. 
MORENO, C. \& FERRO, V.G. 2016. Arctiinae moths (Lepidoptera, Erebidae) of the Emas National Park, Goiás, Brazil. Biota Neotrop. 16(2): e20150037. http://dx.doi.org/10.1590/1676-0611-BN-2015-0037 (last access on 29/02/2020)

OBERTHÜR, C. 1881. Études d'Entomologie: Faunes Entomologiques; descriptions d'insectes nouveaux ou peu connus. Fascicule VI. Imprimier Oberthür, Rennes.

ROTHSCHILD, L.W. 1910a. Descriptions of new species of Arctiinae in the Tring Museum. Novit. Zool. 17(1): 1-85.

ROTHSCHILD, L.W. 1910b. Descriptions of new species of Arctiinae in the Tring Museum. Novit. Zool. 17(2): 113-171.

ROTHSCHILD, L.W. 1922. A preliminary list of the Arctiinae of Pará, Brazil, and a few from other localities. Ann. Mag. Nat. Hist. (ninenth series) 9 (53): 457-494.

ROTHSCHILD, L.W. 1933. New species and subspecies of Arctiinae. Ann. Mag. Nat. Hist. (tenth series) 11(62): 167-194.

SCHERRER, S., FERRO, V.G., RAMOS, M.N. \& DINIZ, I.R. 2013. Species composition and temporal activity of Arctiinae (Lepidoptera: Erebidae) in two cerrado vegetation types. Zoologia 30(2): 200-210.

SCHMIDT, B.C. 2009. A new genus and two new species of arctiine tiger moth (Noctuidae, Arctiinae, Arctiini) from Costa Rica. ZooKeys 9: 89-96. https:// doi.org/10.3897/zookeys.9.151 (last access on 29/02/2020).

SEITZ, A. 1919-1925. 4. Familie: Arctiidae, Bärenspinner. In Die GrossSchmetterlinge der Erde. II. Abteilung: Die Gross-Schmetterlinge des Amerikanischen Faunengebietes. 6. Band. Die Amerikanischen Spinner und Schwärmer (A. Seitz, ed.). Alfred Kernen, Stuttgart, p.231-497.

TESTON, J.A., ABREU, D.S. de \& FERRO, V.G. 2019a. Arctiini Leach, [1815] (Lepidoptera, Erebidae, Arctiinae) of the Brazilian Amazon. III - Subtribe Ctenuchina Kirby, 1837. Biota Neotrop. 19(2): e20180673. http://dx.doi. org/10.1590/1676-0611-bn-2018-0673 (last access on 01/03/2020).

TESTON, J.A., CAMPELO, J. da C., LOPES, A.M.C. \& SPECHT, A. 2019b. First record of Utetheisa pulchella (Linnaeus, 1758) (Lepidoptera: Erebidae: Arctiinae) in Brazilian Amazon: implications for conservation. An. Acad. Bras. Ciênc. 91 (1): e20180262. http://dx.doi.org/10.1590/00013765201920180262 (last access on 28/02/2020).

TESTON, J.A. \& CORREA, D. do C.V. 2015. The Arctiini (Lepidoptera, Erebidae, Arctiinae) fauna of the Serra do Pardo National Park, Pará, Brazil. Check List 11(2): 1-9.

TESTON, J.A. \& DELFINA, M.C. 2010. Diversidade de Arctiinae (Lepidoptera, Arctiidae) em área alterada em Altamira, Amazônia Oriental, Pará, Brasil. Acta Amaz. 40(2): 387-396.
TESTON, J.A. \& FERRO, V.G. 2016a. Arctiini Leach, [1815] (Lepidoptera, Erebidae, Arctiinae) of the Brazilian Amazon. I - Subtribe Phaegopterina Kirby, 1892. Check List 12(2): 1-16.

TESTON, J.A. \& FERRO, V.G. 2016b. Arctiini Leach, [1815] (Lepidoptera, Erebidae, Arctiinae) of the Brazilian Amazon. II - Subtribe Pericopina Walker, [1865]. Check List 12(6): 1-7.

TESTON, J.A. \& FERRO, V.G. 2019. Arctiini Leach, [1815] (Lepidoptera, Erebidae, Arctiinae) of the Brazilian Amazon. IV - Subtribe Euchromiina Butler, 1876. Biota Neotrop. 19(4): e20190747. http://dx.doi org/10.1590/1676-0611-bn-2019-0747 (last access on 01/03/2020).

TRAVASSOS L. 1946. Contribuição ao conhecimento dos "Arctiidae" XI Gênero "Utetheisa" Hübner, 1819. Verificação de "U. pulchella" (L., 1758) Kirby, 1892, no Nordeste do Brasil. Rev Bras Biol 6 (3): 343-354.

VALENTE, D.M.P., ZENKER, M.M. \& TESTON, J.A. 2018. Tiger-Moths in Savannas in Eastern Amazon: First Assessment of Diversity and Seasonal Aspects. Neotrop. Entomol. 47(6): 842-851.

VINCENT, B. \& LAGUERRE, M. 2014. Catalogue of the Neotropical Arctiini Leach, [1815] (except Ctenuchina Kirby, 1837 and Euchromiina Butler, 1876) (Insecta, Lepidoptera, Erebidae, Arctiinae). Zoosystema 36(2): $137-533$

WALKER, F. 1855. List of the specimens of lepidopterous insects in the collection of the British Museum. Part III. - Lepidoptera Heterocera. Edward Newman, London.

WALKER, F. [1865]. List of the specimens of lepidopterous insects in the collection of the British Museum. Part XXXI. - Supplement. Edward Newman, London.

WATSON, A. 1971. An Illustrated Catalogue of the Neotropic Arctiinae Types in the United States National Museum (Lepidoptera: Arctiidae) Part I Smithsonian Contributions to Zoology 50: 1-361.

WATSON, A. 1973. An Illustrated Catalogue of the Neotropic Arctiinae Types in the United States National Museum (Lepidoptera: Arctiidae) Part II Smithsonian Contributions to Zoology 128: 1-160.

WELLER, S.J., DACOSTA, M., SIMMONS, R.B., DITTMAR, K. \& WHITING, M. 2009. Evolution and taxonomic confusion in Arctiidae. In Tiger Moths and Wolly Bears, Behavior, Ecology and Evolution of the Arctiidae (W.E. Conner, ed.). Oxford University Press, New York, p.11-30.

Received: $01 / 03 / 2020$

Revised: $12 / 06 / 2020$

Accepted: 17/06/2020

Published online: 27/07/2020 